\title{
Theoretical substantiation of the influence of electric pulse processing on the process of obtaining juice from grapes and fruits
}

\author{
Nodir Eshpulatov ${ }^{1 *}$, Tolib Khalmuradov ${ }^{2}$, Rakhmanberdi Khalilov ${ }^{2}$, Abdulkhay Obidov $^{2}$, \\ Sobir Nurmanov ${ }^{2}$, and Dilmurat Omonov ${ }^{2}$ \\ ${ }^{1}$ Tashkent Institute of Irrigation and Agricultural Mechanization Engineers, Tashkent, Uzbekistan \\ ${ }^{2}$ Tashkent State Agrarian University, Tashkent, Uzbekistan
}

\begin{abstract}
The article presents the theoretical basis of the effect of electrical pulse processing on the process of obtaining juice from grapes and fruits. High-voltage pulsed electrical processing technology for biological products has a higher damaging effect on living cells than other electrical effects, and this can be achieved due to the passage of large discharges of current through tissues and cells in a short period of time. It has been found that high efficiency in killing living cells by secretion can be achieved as a result of a pulsed energy effect. In order to develop energy-efficient electrical technology for extracting juice from fruits and grapes, it has been found that high-voltage electric pulse discharge treatment of grapes and apples before extracting juice has a good effect. Analytical expressions between electrical impulse processing parameters (pulse energy and capacitor capacity) and juice output were determined. The degree of damage to fruit and grape cells depends on the capacitance of the capacitor, the discharge voltage, and the number of pulses.
\end{abstract}

\section{Introduction}

The rate of juice production depends on the physiological and anatomical properties of the fruit tissue. The protoplasm of a living cell is impermeable to intracellular extractives. The protoplasm prevents the juice from coming out. The main factor determining the amount of sap during pressing is the cell permeability of plant tissue [1-4].

Semi-conductivity of protoplasm is present only in living cells physicochemical properties of the protoplasm change when conditions are not sufficient for the cell to survive. Its viscosity increases, and then the proteins coagulate. The state of the protein determines the permeability of the protoplasm. The protein forms separate solid nodules that fold over the cell membrane. If the effect of adverse factors is not very strong and lasting, after the elimination of these factors, the protoplasm returns to its previous state. That is, the process is stable to a certain extent. Under the strong influence, the protoplasm completely coagulates. The cell dies. The protoplasm of such a cell cannot hold the juice, and it easily comes out of the large cracks that form [12-20].

\footnotetext{
* Corresponding author: nodir_1885@mail.ru
} 
Cell death can be caused by mechanical crushing, heating, freezing, electric shock, ultrasound, and other effects on the fruit.

The above laws apply to all types of vegetable raw materials. At the same time, the protoplasm responds differently to external influences.

The separation of plant sap juice depends on the viscosity, elasticity, and other properties of the protoplasm. These parameters of the protoplasm determine the ability of the raw material to withstand external influences, such as initial processing and pressing. The greater the degradation of the protoplasm as a result of the initial treatment, the greater the sap production $[21,22]$.

The protoplasms of apples, grapes, and cherries are easily broken down by crushing plant tissues, and the amount of juice released during pressing is relatively high. Therefore, such raw material is crushed only mechanically before pressing. Mechanical crushing has little effect on the protoplasm of plums, apricots, black currants. The juice output is very low when pressing such products. To increase the amount of juice, it is necessary to use more destructive effects on the cell protoplasm of these fruits [24, 25, 26, 27, 28, 29].

Juice yield can be increased by adding cellulose fibers, perlite, kieselgur, wood shavings, and other inert substances to the pulp. It is advisable to add cellulose fibers 1-10 $\mathrm{mm}$ long before crushing the raw material.

These materials are added to the enzyme-treated pulp and are highly effective in producing juices in continuous presses.

Long fibrous cellulose spreads irregularly in the brain. The fibers absorb the juice, swell and form a lattice structure. Channels form in the solid particles of the pulp that are squeezed between the fibers, through which pure juice flows without solid particles.

\section{Methods}

According to Flaumenbaum B.L. the yield of juice can be found in the following expression, depending on the structure of the raw material and the preparation of the pulp [5]:

$$
B=A\left(\varphi_{1}+\varphi_{2}\right) I K
$$

where: $\mathrm{B}$ is the amount of juice in the press, $\%$; A is the amount of juice in the fruit; $\varphi_{1}$ and $\varphi_{2}$ are the degree of disintegration of the mesoplastic protoplasm due to initial processing and pressing; $\varphi_{1}$ varies from 0 to $1, \varphi_{2}$ - from 0 to 0,2 ; the amount $\varphi_{1}+\varphi_{2}$ does not exceed $1 ; I-$ the coefficient of loss due to the compression of the juice in the press residue and the coagulation of the pulp ( $I=0,85-0,95$ oralig'ida o'zgaradi); $\mathrm{K}$ is the degree of skeletal integrity (for apples, grapes and cherries, $\mathrm{K}$ is in the range of 0.8 1 , for plums in the range of 0 to 0.7 ). The yield of juice depends mainly on the amount of juice in the processed fruit, the degree of degradation of the protoplasm during the initial processing of the raw material, the structure of the pulp, as well as the design and pressing mode. 


\section{Results and Discussion}

(1)-expression value $\boldsymbol{\varphi}_{1}$ was found to be up to $30 \%$ disruption of the cell protoplasm when the fruit was crushed $[5,6]$. The value of this $\varphi_{1}$ expression can be written as a result of the initial processing before pressing.

$$
\varphi_{1}=\varphi_{1}^{\prime}+\varphi_{1}^{\prime \prime}
$$

where: $\varphi_{1}^{\prime}$ is d degree of destruction of the protoplasmic shell during fruit crushing varies from 0 to 0.3 .

$\varphi_{1}^{\prime \prime}$ the degree of degradation of the protoplasmic shell as a result of electrical pulse treatment before pressing the fruit varies in the range of 0.1-0.5.

Substituting (2) into (1), we get.

$$
B=A\left(\varphi_{1}^{\prime}+\varphi_{1}^{\prime \prime}+\varphi_{2}\right) I K
$$

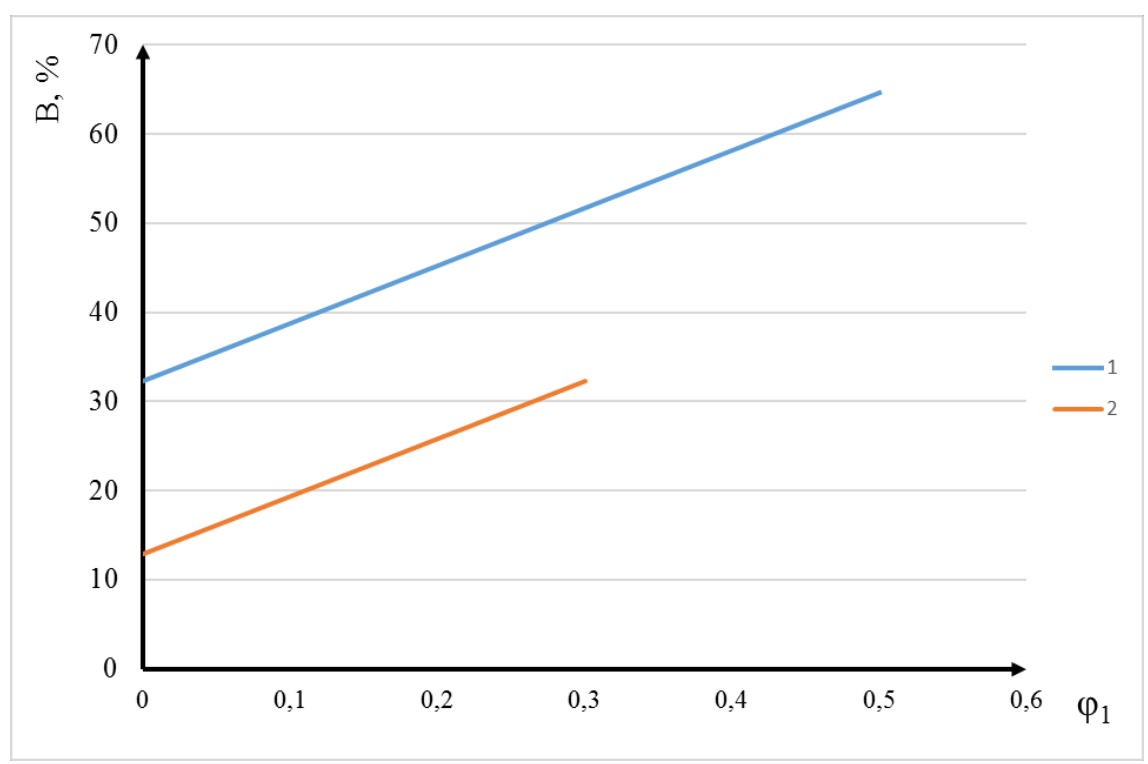

Fig. 1. (3)- solve the equation graphically.

Here: $1-B=f\left(\varphi_{1}^{\prime \prime}\right), \varphi_{1}^{\prime}=0,3, \varphi_{2}=0,2 ; 2-B=f\left(\varphi_{1}^{\prime}\right), \varphi_{1}^{\prime \prime}=0, \varphi_{2}=0,2$.

As is seen from the graph, the value of $\varphi_{1}^{\prime \prime}$ increases, the juice yield increases during pressing.

To determine the value of $\varphi_{1}^{\prime \prime}$, it is necessary to find the relationship between the degree of damage $\mathrm{S}$ (ranging from 0 to $95 \%$ ) as a result of electrical pulse processing. 


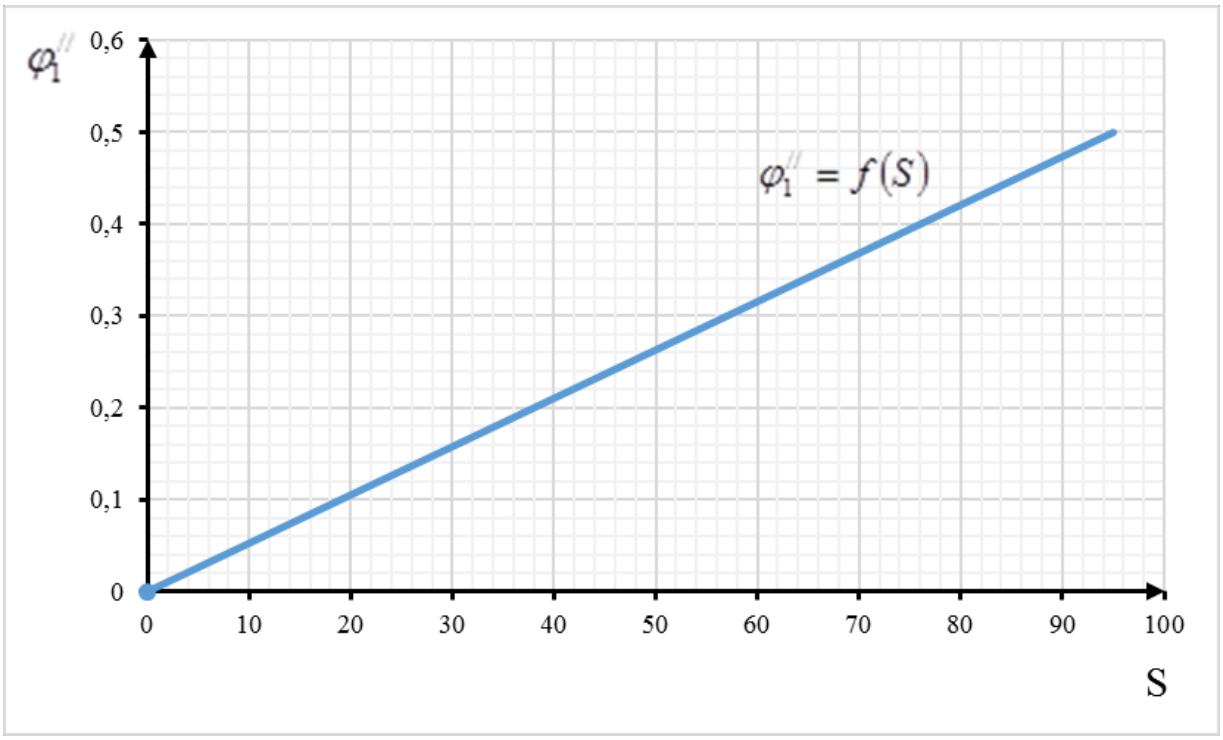

Fig. 2. Graphical correlation to determine the value of

We propose a graph-analytical method of using the dependence in Figure 2 to determine the value of $\varphi_{1}^{\prime \prime}$ in the (3) expression. The value $\varphi_{1}^{\prime \prime}$ can be determined for each number of degrees of damage in the graph.

Thus, expression (3) represents the process of obtaining juice by electric pulse processing.

A.Ya.Papchenko, Yu.A.Sheglov, and V.G.Chebanu determined the amount of electrical juice $(\mathrm{B}, \%)$ from plant products as follows $[6]$ :

1) For apples and pears

$$
B=68 \exp \left[0,01\left(12-\sqrt[3]{\frac{500 K_{T}}{T 0,05 t}}-p^{2}+5 p+0,16 E\right)\right]
$$

2) for sugar beets

$$
B=74 \exp \left[0,01\left(12-\sqrt[3]{\frac{500 K_{T}}{T 0,05 t}}-p^{2}+5 p+0,16 E\right)\right]
$$

3) for grapes

$$
B=8 \exp \left[0,01\left(12-\sqrt[3]{\frac{500 K_{T}}{T 0,05 t}}-0,16 E\right)\right]
$$

where: $\mathrm{p}$ is the size of the crushed pieces;

$K_{T}$ is current resistance coefficient of plant products, for apples - 1; pear - 1.25; “Aleppo" grapes - 0.9; In "noa" grapes - 9; in sugar beet - 10 g.T - temperature, ${ }^{0} \mathrm{C}$;

$\mathrm{t}$ is duration of electrical processing, $\mathrm{s}$; 
E is electric field strength, $\mathrm{V} / \mathrm{cm}$.

A.Ya.Papchenko and P.N.Montik created a mathematical model of the yield of juice and the duration of electrical processing in the production of juice from plant products [7]:

$$
T=4835,475(0,1 \cdot B)^{1,141} \cdot p^{0,1838} \cdot Д^{0,1638} \cdot C^{0,0856} \cdot(0,01 E)^{-3,447},
$$

Here, B is the juice output, $\%$; $\mathrm{T}$ - duration of electrical processing, ms; $\mathrm{p}$ is the size of the crushed pieces, mm; $\mathrm{D}$ is duration of electrical pulses, $\mathrm{ms}$; $\mathrm{C}$ is the value of the pulpjuice ratio; $\mathrm{E}$ is electric field strength, $\mathrm{V} / \mathrm{cm}$.

Expressions 4-7 describe the process of obtaining juice by electric processing and allow to determine the relationship between the parameters of the electric pulse processing and the output of juice for specific cases. Based on these expressions, it is necessary to determine whether the parameters of electrical pulse processing depend on the juice output.

The duration of electrical processing is determined by the following expression:

$$
t=3 \cdot 10^{3} \rho K_{T} /\left(E^{3} T\right)
$$

Substituting (2.6) into (2.4) and (2.6), the juice yield is as follows:

For apples and pears: $B=68 \exp \left[0,01\left(12-E_{3} \sqrt{\frac{3,3}{\rho}}-p^{2}+5 p+0,16 E\right)\right]$

For grapes: $B=68 \exp \left[0,01\left(12-E\left(\sqrt[3]{\frac{3,3}{\rho}}+0,16\right)\right)\right]$

The electric field strength is as follows:

$$
E=\frac{U}{l}
$$

The energy of an electric pulse discharge is determined as follows:

$$
W=\frac{1}{2} C U^{2}, \text { or } U=\sqrt{\frac{2 W}{C}}
$$

Summarizing the expressions (9) (12), the juice yield is as follows: For apples and pears:

$$
B=68 \exp \left[0,01\left(12-\frac{1}{l} \cdot \sqrt{\frac{2 W}{C}}\left(\sqrt[3]{\frac{3,3}{\rho}}+0,16\right)-p^{2}+5 p\right)\right]
$$

For grapes: $B=68 \exp \left[0,01\left(12-\frac{1}{l} \cdot \sqrt{\frac{2 W}{C}}\left(\sqrt[3]{\frac{3,3}{\rho}}+0,16\right)\right)\right]$

Expressions (13) and (14) fully represent the dependence of fruit and grape juice production on electrical pulse processing.

The electrical effects of plant products on living cells are reflected in biological and structural changes. Several authors have stated in their research that any living organism 
responds to internal influences. Hence many researchers (Reshetko E.V., Boyko A.V., Sarochanu N.S., and others) have proposed that a mathematical description of the electrophysical factors that affect the activity of living organisms [8, 9, 30, 31, 32]. They measured the degree of damage to plant material cells in relative units or percentages. Identified a mathematical description that characterizes the relationship between the degree of damage to a material and the parameters of the influencing factor. In determining the relationship between changes in the degree of damage to plant cells and the laws of electric pulse processing, it is necessary to determine the relationship between the main factors of electric pulse discharge processing $(\mathrm{U}, \mathrm{C}, \mathrm{n})$ and the degree of damage to the material [33, $34,35,36,37,38]$. Sarochanu N.S. proposed to find the relationship between the degree of cell damage $\left(\mathrm{S}_{\mathrm{n}}\right)$ and the parameters of the electrical impact $(\mathrm{E}, \tau)$ of the plant material cell by the following formula:

$$
S_{n}=\alpha \cdot E \cdot k \cdot \tau
$$

where: $\boldsymbol{\alpha}$ is coefficient of proportionality; $E$ is electric field strength; $k$ is degree indicator; $\tau$ is- impact time.

Reshetka E.V. Reshetko E.V. described the degree of cell damage as follows:

$$
\begin{aligned}
& S=S_{o}+e^{\mu} \\
& \mu=a+b\left[\left(E-E_{o}\right)+c \ln \left(E-E_{o}\right)\right]
\end{aligned}
$$

where: $S_{o}$ is he degree of initial damage; $a, b, c$ are the coefficient that characterizes the appearance of the product; $E_{o}, E$ is initial and current values of electric field strength.

In his research, A. Radjabov identified the equations of the process of electric pulse processing of plant materials (fruits and grapes), that is, described the degree of damage to plant material by electric pulse processing $[10,11,15,16,23]$ :

$$
S=S_{0} e^{\frac{-Q_{s i} n}{K_{i}}}+S_{\max }\left(1-e^{\frac{-Q_{s i} n}{K_{i}}}\right)
$$

where: $S_{o}$ and $S_{\max }$ - the initial and maximum value of the degree of damage to plant material; $Q_{s i}$ is single pulse energy, $\mathrm{J} ; \boldsymbol{n}$ is number of pulses, pcs; $K_{i \text { - a }}$ coefficient that characterizes the decrease in the effect of injury on the latter relative to the previous impulse.

(Substituting expression (2.12) into expression (2.17), we get the following:

$$
S=S_{0} e^{\frac{-C \cdot U^{2} \cdot n}{2 K_{i}}}+S_{\max }\left(1-e^{\frac{-C \cdot U^{2} \cdot n}{2 K_{i}}}\right)
$$


The study of the $K_{i}$ coefficient showed that it depends on the number of pulses and the product type. Based on experimental studies, it was found that the value of the $K_{i}$ coefficient varies in the range of 0.12-0.32 for apples and 0.18-0.38 for grapes.

It can be seen from this expression that the degree of damage depends on the discharge voltage (U), the capacitance of the capacitor (S), and the number of pulses (n).

The theoretical expression (18) characterizes the efficiency of electric pulse processing before extracting juice from fruits and grapes.

\section{Conclusions}

1. It was found that the yield of juice from fruits and grapes depends on the degree of degradation of the protoplasmic shell as a result of electrical pulse treatment before pressing the fruit. The value of the degree of degradation of the cell protoplasmic membrane $\varphi_{1}^{\prime \prime}$ was determined by graph-analytical methods for each value of the degree of damage (S).

2. Theoretical studies revealed analytical expressions between the parameters of electrical pulse processing and juice output. The degree of damage depends on the capacitance of the capacitor, the discharge voltage and the number of pulses.

\section{References}

1 Botoshan N.I., Bologa M.K., Berzoy S.E. Cellular model of electroplasmolysis. // Electronic processing of materials. 2004. No. 5. - p. 60-64.

2 Zhilkin VM, Gribkov AN, Muromtsev Yu.L. Evaluation of the effectiveness of the process of preparing plant materials for dehydration. // Bulletin of TSTU. 2009, 15 (2), - p. 410-415.

3 Kulneva N.G., Fedoruk V.A. Application of electrophysical methods in sugar production. // Collection of reports of the jubilee international scientific and practical conference "Food products of the XXI century." Volume 1. - Moscow 2001. - p. 219 220.

4 Mikhailova T.N. Efficiency of electric treatment of apple shavings for intensification of pressing for juice production. // Food and processing industry. 2003. (1), - pp. 289291.

5 Flaumenbaum B.L. Canning technology for fruits, vegetables, meat and fish. - 2nd ed., Rev. and add. - M .: "Kolos", 1993. - 320 p.

6 Papchenko A.Ya., Shcheglov Yu.A., Chebanu V.G. Calculation of an electroplasmolyzer for electrical processing of plant materials. // Electronic processing of materials. 1984. No. 3. - S. 81-84.

7 Papchenko A.Ya., Montik N.P. Optimization of the process of electrical processing of plant materials. // Electronic processing of materials. 1978. No. 1. - S. 74-76.

8 Reshetko E.V. Study of electroplasmolysis. // Mechanization and electrification of social agriculture. - 1977. No. 12. - S. 11-13.

9 Boyko N.I., Bondina N.N., Mikhailov V.M. Modeling the effect of an electric field on objects with a multilayer structure. // Electronic modeling. 2002. T. 24. No. 1. - S. 7082.

10 Radjabov A, Ibragimov M., Salomov M. Electro impuls treatment - energy efficiency factor during drying of agricultural products. International Journal of Electrical and 
Electronics Engineering Research (IJEEER), ISSN (P): 2250-155X; ISSN (E): 2278943X; Vol. 9, Issue 1, Jun 2019, p. 1-14

11 Radjabov A., Eshpulatov N., Nabiyev S. Reserves for energy efficiency in processing and storage of fruit and vegetable products in the republic of Uzbekistan. International Journal of Electrical and Electronics Engineering Research (IJEEER). ISSN (P): 2250-155X; ISSN (E): 2278-943X; Vol. 8, Issue 4, Dec 2018, p. 1-10

12 Ibragimov M., Eshpulatov N., Matchanov O.Q., Nuraliyev S. Statics and kinetics of decreasing the moisture content of technical seeds. International Journal of Advanced Research in Science, Engineering and Technology Vol. 7, Issue 2, February 2020.

13 Sayfutdinov R.S., Mukhitdinov U.D., Eshpulatov N. Increasing Reactivity Cotton Cellulose Intended For Acetylation. International Journal of Research. Volume 07. Issue 04. April 2020. - P. 854-860.

14 Sayfutdinov R.S., Mukhitdinov U.D., Eshpulatov N.M. (2020) Research of increasing the reactivity cotton cellulose intended for chemistry. Technical science and innovation: Vol. 2020: Iss.1, Article 10. Available at: https://uzjournals.edu.uz/btstu/vol2020/iss1/10

15 Radjabov A., Ibragimov M., Eshpulatov N.M., Matchonov, O. Improving the energy performance of ozone generators used in agricultural ecology. Journal of Physics: Conference Series. Volume 1399, Issue 5, 5 December 2019, 055060.

16 Radjabov, A., Berdishev, A.S., Mussabekov, A.T. Autonomous Complex for Water Disinfection in Rural Areas of Uzbekistan. Applied Solar Energy (English translation of Geliotekhnika). Volume 55, Issue 2, 1 March 2019, p.113-118.

17 Ibragimov M., Eshpulatov N., Matchanov O. Electrical technology of moisture content reduction of industrial-grade cotton seeds. (2020) IOP Conference Series: Materials Science and Engineering. 883(1), 012135.

18 Sayfutdinov R.S., Mukhitdinov U.D., Eshpulatov N.M. Increasing reactivity of cotton celluloses for chemical processing. (2020) IOP Conference Series: Materials Science and Engineering. 883(1), 012133.

19 Eshpulatov N.M., Salomov M.N., Fayzullaev B.P. Energy characteristics in artificial energy systems. Actual problems of agricultural science, production and education. Voronezh, April 15, 2016. - p. 142-144.

20 Yusubaliev A. Electric sorting in cotton growing: monograph / A. Yusubaliev; Tashkent Institute of Irrigation and Agricultural Mechanization Engineers. Novosibirsk: Akademizdat, 2019. - 176 p.

21 Bayzakova J.S., Abdildin N.K., Shynybay Zh.S., Chingenzhinova Zh.S., Berdyshev A.S., Eshpulatov N.M., Matchonov O.Q., Yusupov Sh.B. Methodology for conducting an optimization experiment for harvesting dry short-stalked grain crops. IOP Conf. Series: Earth and Environmental Science. 614 (2020) 012118.

22 Ibragimov M., Eshpulatov N., Matchanov O. Substantiation of the optimal parameters by processing with electric contact methods to decrease the moisture content of technical seeds. IOP Conf. Series: Earth and Environmental Science. 614 (2020) 012018.

23 Radjabov A., Ibragimov M., Eshpulatov N. The study of the electrical conductivity of Apples and Grapes as an object of electrical processing. E3S Web of Conferences, 2021, 226, 00002.

24 Choriev J., Muslimov T., Abduraupov R, Khalimbetov A., Abdurakhmonov S. Fundamentals of developing and designing portable weirs for farmlands. IOP Conf. Series: Materials Science and Engineering. 869 (2020) 072023.

25 Radjabov A., Berdishev A.S., Mussabekov A.T. Autonomous Complex for Water Disinfection in Rural Areas of Uzbekistan. Applied Solar Energy (English translation of Geliotekhnika), 2019, 55(2), pp. 113-118 
26 Taslimov A.D., Berdishev A.S., Melikuziev M.V., Rakhimov F.M. Method of choosing the unification of cable sections of electric network cables under conditions of load development uncertainty. E3S Web of Conferences, 2019, 139, 01081.

27 Taslimov A.D., Berdishev A.S., Melikuziev M.V., Rakhimov F.M. Method of selecting parameters of cable lines distributive networks $10 \mathrm{kv}$ in uncertainty conditions. E3S Web of Conferences, 2019, 139, 01082.

28 Taslimov A.D., Berdishev A.S., Rakhimov F.M., Yuldashev A.A. Optimal tendency of selecting cable cross-sections for agricultural electrical networks. Journal of Physics: Conference Series, 2020, 1515(2), 022056.

29 Berdishev A., Taslimov A., Melikuziev B., Bijanov A. Reliability indicators of $10 \mathrm{kV}$ cable lines in rural areas. IOP Conference Series: Materials Science and Engineering, 2020, 869(2), 022005.

30 Rakhmonov I., Berdishev A., Niyozov N., Muratov A., Khaliknazarov U. Development of a scheme for generating the predicted value of specific electricity consumption. IOP Conference Series: Materials Science and Engineering, 2020, 883(1), 012103.

31 Bakhadirov I., Markaev N., Aslanova G., Tanatarov R., Makhmuthonov S. Differentiated tariffs of electricity for the improvement of steelmaking Uzbekistan. IOP Conference Series: Materials Science and Engineering, 2020, 883(1), 012121.

32 Taslimov A., Rakhimov F., L.Nematov, Markaev N., Bijanov A., Yunusov R. Economic load intervals for selecting $10 \mathrm{kV}$ cable cross-sections for agricultural consumers. IOP Conference Series: Materials Science and Engineering, 2020, 883(1), 012102 .

33 Isakov A., Abdullaev Z. Study on increase of operation efficiency of electrical energy and electrical equipment. 2020 IOP Conf. Ser.: Earth and Environmental Science 614(1) 012047.

34 Isakov A., Rakhmatov A., Ismailova Z. Study the effect of the design of discharge electrodes on the characteristics of the corona discharge. 2020 IOP Conf. Ser.: Earth and Environmental Science 614(1) 012011.

35 Mirzabaev A., Isakov A., Mirzabekov S., Makhkamov T., Kodirov D. Problems of integration of the photovoltaic power stations with the grid systems. 2020 IOP Conf. Ser.: Earth and Environmental Science 614(1) 012016.

36 Muzafarov S., Balitskiy V., Toqaev B., Batirova L., Isakov A. The research results of cleaning air stream process from aerosol particles in electric fields of corona discharge stream form. 2020 IOP Conf. Ser.: Earth and Environmental Science 614(1) 012008.

37 Isakov A., Mirzabaev A., Sitdikov O., Makhkamova M., Kodirov D. Innovative methods of developing solar power systems for remote and agricultural facilities in Uzbekistan. 2020 IOP Conf. Ser.: Earth and Environmental Science

38 Isakov A., Rakhmatov A. Control over parameters of ionized air. 2020 IOP Conf. Ser.: Mater. Sci. Eng. 883(1) 012118. 